\title{
Alleviating Effects of Euphorbiae humifusae L. Extract on the Neurotoxicity Induced by Lead
}

\author{
Sang-Hee Lee ${ }^{1}$, Young-Mi Seo ${ }^{2}$ \\ ${ }^{1}$ Department of Internal Medicine, Sanbon Hospital, School of Medicine, Wonkwang University, Gunpo, Korea \\ ${ }^{2}$ Department of Nursing, College of Medicine, Wonkwang Health Science University, Iksan, Korea
}

\section{납의 신경독성에 대한 지금초 추출물의 독성경감 효과}

\author{
이상희 ${ }^{1}$, 서영미 ${ }^{2}$ \\ ${ }^{1}$ 원광대학교 의과대학 산본병원 내과, ${ }^{2}$ 원광보건대학교 간호학과
}

\begin{abstract}
This study examined the neurotoxicity induced by lead acetate (LA) on cultured C6 glioma cells and the protective effects of Euphorbiae humifusae L. (EH) extract against LA-induced cytotoxicity. In this study, LA exhibited neurotoxicity in a dose-dependent manner compared to the control, and was determined to be highly-toxic according to the toxic criteria. The XTT 50 value of LA was calculated at a concentration of $38.6 \mu \mathrm{M}$ after C6 glioma cells were incubated for 72 hours in the media containing 30 50 $\mu \mathrm{M}$ of LA, respectively. In addition, LA-induced neurotoxicity was suggested to correlate with the level of oxidative stress because vitamin $\mathrm{E}$, an antioxidant, increased the cell viability damaged by LA-induced cytotoxicity. The EH extract effectively prevented cell injury from LA-induced cytotoxicity via its antioxidative effects, such as inhibitory ability of lipid peroxidation, superoxide dismutase-like activity and 1,1-diphenyl-2-picrylhydrazyl-radical scavenging activity. These antioxidative effects may result in components, such as polyphenol or flavonoids including gallic acid or quercetin. In conclusion, natural resources, such as EH extracts, may be a useful putative agent for the treatment of diseases associated with oxidative stress, such as lead neurotoxicity.
\end{abstract}

Key words: Antioxidative effect, Neurotoxicity, Oxidative stress

This is an Open Access article distributed under the terms of the Creative Commons Attribution Non-Commercial License (http://creativecommons.org/licenses/by-nc/4.0) which permits unrestricted non-commercial use, distribution, and reproduction in any medium, provided the original work is properly cited.

Copyright @ 2018 The Korean Society for Clinical Laboratory Science. All rights reserved.
Corresponding author: Young-Mi Seo Department of Nursing, College of Medicine, Wonkwang Health Science University, 514 Iksandae-ro, Iksan 54538, Korea Tel: 82-63-840-1314

Fax: 82-63-840-1319

E-mail: dudn0408@wu.ac.kr

Received: November 1, 2018 Revised: November 29, 2018

Accepted: December 3, 2018

\section{서 론}

납은 은백색의 연한 중금속류로 용점이 낮아산업공정 중 공 기중에서 쉽게 가열됨으로서 흄(fume)이나 미세입자의 분진이 되어 호흡기나 피부를 통해 인체에 노출된다[1]. 납이 일단 인체 내에 축적되면 체외로 배출되는데 오랜 시간이 필요할 뿐만 아 니라, 뼈를 비롯한 허파나 근육과 같은 조직에 침착되고, 혈액내 혈류를 타고 온몸의 여러 장기에 도달하여 납중독을 유발한다 는 사실은 이미 잘 알려져 있다[2]. 납은 산업공정에서 축전지제
조를 비롯해서 자동차부품, 페인트 제조 및 인쇄 공정 등에 사용 될 뿐만 아니라, 최근에는 어린이의 각종 장난감이나 놀이기구 에도 함유되어 있다고 알려지면서 취급 시 각별한 주의를 요하 고 있다[3]. 납중독은 조혈작용이나 신장기능에 영향을 미칠 뿐 만 아니라 특히, 신경조직에 심각한 영향을 주어 피로를 동반한 두통은 물론, 수면장애, 기억장애, 초조감 또는 경련과 같은 신 경계통의 불안정성을 초래한다[4]. 따라서, 납중독을 예방하거 나 치료할 수 있는 새로운 치료제나 또는 효과적인 치료방법을 확립하는 것이 시급한 문제다. 그러나 아직까지 납중독에 노출 
된 경우 penicillamine과 같은 납 배설 촉진제나 안정제 또는 진 정제와 같은 처치가 있지만 치료에는 매우 미흡한 실정이다[5]. 최근에 치매(dementia)를 포함한 당뇨나 파킨슨병과 같은 난치성 질환은 물론, 납의 신경독성이나[6], 중금속류에 속하는 수은이나 크롬의 신경독성 원인의 하나로 자유라디칼이 제시되 고 있다. 실제, 수은이나 크롬과 같은 중금속류는 이들이 붕괴될 때 산소라디칼이나 메틸라디칼을 발생하게 되며, 이들의 독성 이 산화적 손상과 관련 있다고 보고되었다[7]. 따라서, 이들의 독성 중독에 의한 질환 치료를 항산화 측면에서 시도하려는 노 력이 이루어지고 있다[8]. 자유라디칼은 인체의 대사과정 중에 소량이 생성되고, 몸속의 catalase (CAT)나 superoxide dismutase (SOD)와 같은 항산화 효소에 의하여 물로 변환되어 인 체에는 아무런 영향을 주지 않는다[9]. 자유라디칼은 N-methyl-D-aspartate (NMDA) 수용체의 과활성을 통해 세포내 다 량의 칼슘 유입은 물론, 산소와 질소 자유라디칼 간의 융합에 의 한 peroxynitrite라는 독성물질의 형성[10] 및 nuclear factor kappa B (NF-kB)와 같은 핵전사인자의 과활성 및 tumor necrosis factor (TNF)- $\alpha$ 나 interleukin (IL)-4와 같은 염증매 개물질의 방출 등의 현상을 초래하여 병변을 더욱 악화시킨다 [11].

최근, 화학적 성분분석방법이 개발되면서 각종 식물을 비롯 한 한약재나 약초에 항산화를 비롯한 항염, 항균, 항암 등에 유 효한 생리활성물질이 다량함유되어 있다고 밝혀지면서 이들을 이용해 질환을 치료하려는 시도가 이루어지고 있다[4]. 이들의 성분에는 페놀화합물(phenolic compound)을 비롯해 이소프 레노이드(isoprenoids) 및 당배당체(glycoside)와 같은 다양한 물질들이 추출정제되어 있다. 특히, flavonol이나 isoflavones, quercetin, tannin과 같은 성분들은 항산화작용이나 항염 작용 이 뛰어나 염증이나 세균 증식을 억제하는 중요한 역할을 한다 [12]. 식물 중 지금초(Euphorbiae humifusae L., EH)는 대극과 (Euphorbiaceae)에 속하는 일년생 초본으로 우리나라의 밭이 랑이나 길가 또는 황무지 등에 서식하고 있다. 꽃은 6 8월경에 개화하는데 여름에서 가을 사이에 전초를 채취해 햇볕에 말려 약재로 사용한다. $\mathrm{EH}$ 의 맛은 맵고 성질은 평해서 옹기 창독을 비롯한 지혈, 장염, 이질 등의 치료에 사용된다[13]. 함유성분으 로는 pyrocatechol을 비롯해 gallic acid, flavonol, quercetin 과 같은 여러 종류의 항산화 물질이 있다[14]. 분석 기술의 발달 과 함께 세포배양기술이 널리 보급되면서 배양 세포를 이용하 여 화학 약제의 안전성이나 효능 검정은 물론, 특정 세포에 대한 각종 성장 인자에 의한 세포 분화나 특성을 연구하여 이를 질병 치료에 적용하려는 연구가 이루어지고 있다[15]. 배양 세포는
생체에서와 동일하게 독성에 의한 DNA 손상을 비롯하여 단백 질합성저해 또는 산화적 손상에 의한 세포 구조 변화 및 대사물 질의 생성 저하와 같은 다양한 요인에 의하여 세포의 퇴화나 사 멸을 초래하게 된다[16]. 따라서, 본 연구에서는 C6 glioma 배 양 세포를 재료로 초산납(lead acetate, LA)에 대한 독성과 이에 대한 EH 추출물의 경감 효과 조사의 하나로, XTT분석에 의한 대사물질의 생성 변화양상을 세포 생존율 측면에서 조사하였으 며, 동시에 이에 대한 형태적 변화를 관찰하였다. 또한, LA 신경 독성 원인의 하나로 산화적 손상과의 연관성을 조사함으로서 독성 경감 내지는 방어를 항산화 측면에서 접근하기 위하여 $\mathrm{EH}$ 추출물에 대한 지질과산화(lipid peroxidation, LP) 억제능을 비롯하여 superoxide dismutase (SOD)-유사 활성 및 1,1-diphenyl-2-picrylhydrazyl (DPPH)-radical 소거능을 측정함으로서 납중독과 같은 중금속류의 독성을 개선 내지는 치료할 수 있는 물질을 천연소재로부터 탐색하였다.

\section{재료 및 방법}

\section{1. 세포 배양}

C6 glioma 세포(ATCC, CCL 107)의 배양은 Chen 등[17]의 방법에 따라 행하였다. 즉, $35 \mathrm{~mm}$ petri dish (Falcon, BD Bioscience, MA, USA) 에서 3일 마다 세척과 새로운 배양액으 로 교환하면서 3회 계대 배양한 세포에 $0.025 \%$ trypsin을 이용 하여 배양용기로부터 세포를 분리시켰다. 분리된 세포는 $10 \%$ FBS가 포함된 배양액에 넣어 균질화 시킨 후 $1 \times 10^{5}$ cells/well 의 밀도로 96-well 용기에 배분하였다. 배분된 세포는 $36^{\circ} \mathrm{C}$, $5 \% \mathrm{CO}_{2}$ 로 조절된 정온기에서 72 시간 동안 배양하였다.

\section{2. 약제 제조}

본 실험에 사용한 시약으로는 $\mathrm{LA}$ 를 비롯하여 vitamin $\mathrm{E}$, 1,1-diphenyl-2-picrylhydrazyl (DPPH), pyrogallol, hydrochloride $(\mathrm{HCl})$, dimetylsulfoxide (DMSO), trypsin, linoleic acid, ferrous chloride, 2,3-bis-(2-methoxy-4nitro-5-sullfophenyl)-2H-tetrazolium-5-carboxanilide (XTT)는 Sigma-Alderich사(Sigma Chemical, St. Louis. MO, USA)에서 구입하였다. 또한, Minimum essential medium (MEM), fetal bovine serum (FBS)은 Gibco사(Grand Island, $\mathrm{NY}, \mathrm{USA}$ )에서 구입하였다. 미국산업보건청(Occupational Safety and Health Administration, OSHA)의 노출허용기준 (permissible exposure limit, PEL)에서 공시한 작업장을 기준 으로 한 인체의 납 허용한계농도는 $0.05 \mathrm{mg} / \mathrm{m}^{3}$ 로, 미국산업위 
생전문가협회(American Conference of Governmental Industrial Hygienists, ACGIH)와 우리나라산업안전보건법 (노동부 고시 제88-69호)에서는 $0.15 \mathrm{mg} / \mathrm{m}^{3}$ 로 각각 정하고 있 다. 동물실험에 있어서는 우리나라 국립환경연구원(환경자료 집, 1999)에 의한 백서의 $\mathrm{LA}$ 치사량 $\left(\mathrm{LCL}_{0}\right)$ 은 $270 \mathrm{mg} / \mathrm{kg}$ 으로 되 어 있다. 반면, 각 배양 세포에 대한 LA의 $\mathrm{LC}_{50}$ 값은 아직 정립되 어 있지 않다. 따라서, 본 연구에서는 배양 C6 glioma 세포[4, 28]와 배양 NIH 3T3 섬유모세포[5, 27]에 대한 타 연구에서 LA 의 $\mathrm{LC}_{50}\left(\mathrm{XTT}_{50}\right)$ 값이 각각 $30 \sim 50 \mu \mathrm{M}$ 에서 나타남으로서 이를 근거로 처리 농도를 0 50 $\mu \mathrm{M}$ 로 하여 XTT90 (lower-toxic)과 $\mathrm{XTT}_{50}$ (higher-toxic)을 측정하였다. 동시에 이 범위를 벗어날 것을 대비하여 LA의 제조는 $50 \mu \mathrm{M}, 100 \mu \mathrm{M}, 150 \mu \mathrm{M}, 200 \mu \mathrm{M}$ 의 저장액을, XTT는 $50 \mu \mathrm{g} / \mathrm{mL}$ 농도의 저장액을 각각 만들어 냉암소에 보관 후 실험 당일 일정 농도로 희석하여 사용하였다.

\section{3. 지금초 (Euphorbiae humifusae L., EH) 추출}

전북 김제의 야산에서 5 7월경 $\mathrm{EH}$ 를 채취한 후 대학부설 생 명자원과학연구소에서 동정 확인후 사용하였다. 채취한 전초 는 3회 깨끗이 수세한 다음 일정 길이로 잘라 냉암소에 보관하 여 시료로 사용하였다. 시료 추출을 위하여 보관 중인 시료 73.8 $\mathrm{g}$ 을 잘게 파쇄한 후 시료의 3 배 정도의 물과 함께 $1,000 \mathrm{~mL}$ 의 환저 플라스크에 넣고 3 시간 동안 가열하였다. 위의 과정을 3 회 반복하여 추출된 액을 모아 여과한 다음 $3,000 \mathrm{rpm}$ 에서 30분 동안 원침 시킨 후 진공농축기에서 농축감압시킨 다음 $3.5 \mathrm{~g}$ 의 시료를 얻었다. 이 때 수율은 $4.7 \%$ 로 나타났다.

\section{4. 초산납(LA) 처리}

$\mathrm{LA}$ 독성 측정을 위한 $\mathrm{XTT}_{90}$ 과 $\mathrm{XTT}_{50}$ 을 조사하기 위하여 96-well plate에 배양이 완료된 세포에 LA가 0 50 $\mu \mathrm{M}$ 로 각각 포함된 배양액 $100 \mu \mathrm{L}$ 를 넣고 72 시간 동안 배양한 후 이의 영향 을 세포 생존율 측정방법에 의하여 대조군과 비교 조사하였다.

\section{LA에 대한 항산화제의 영향}

배양 세포에 $\mathrm{XTT}_{50}$ 농도의 $\mathrm{LA}_{\mathrm{e}}$ 를 처리하기 전에 항산화제인 vitamin $\mathrm{E}$ 를 처리하기 위하여 저자들이 시행하였던 vitamin E 에 대한 항산화능 연구[4]를 근거로 항산화능이 $70 \%$ 이상인 30 $\mu \mathrm{M}$ 과 $40 \mu \mathrm{M}$ 을 농도로 정하였다. 따라서, 위 농도의 vitamin $\mathrm{E}$ 가 각각 포함된 배양액에서 세포를 2 시간 동안 전 처리한 다음 이의 영향을 세포 생존율 측정방법에 의하여 LA만의 처리와 비 교 조사하였다. 또한, 항산화능 분석에 있어서는 양성대조군으 로 항산화능이 더 높은 $40 \mu \mathrm{M}$ 을 중심으로 비교 분석하였다.

\section{6. $\mathrm{EH}$ 추출물의 세포독성 측정}

$1 \times 10^{5}$ cells/well의 밀도로 96-plate에 3일 동안 배양 완료 된 세포를 PBS로 1회 세척 후 minimum essential medium (MEM) 배양액에 10 130 $\mu \mathrm{g} / \mathrm{mL}$ 농도로 각각 희석된 추출액 $100 \mu \mathrm{L}$ 을 각각 넣고 $36^{\circ} \mathrm{C}, 5 \% \mathrm{CO}_{2}$ 로 조절된 정온기에서 72 시 간 동안 배양하였다. 배양 완료 후 세포 생존율 측정방법에 의하 여 대조군과 비교 조사하였다. $\mathrm{EH}$ 추출물에 대한 효능 분석을 위하여 $\mathrm{EH}$ 추출물의 처리 농도는 본 실험의 LA에 대한 세포독 성 결과를 근거로 최대허용농도 이하인 $70 \mu \mathrm{g} / \mathrm{mL}$ 와 100 $\mu \mathrm{g} / \mathrm{mL}$ 로 하였다.

\section{7. $\mathrm{LA}$ 에 대한 $\mathrm{EH}$ 추출물의 영향}

$\mathrm{LA}$ 에 대한 $\mathrm{EH}$ 추출물의 영향을 조사하기 위하여 $\mathrm{XTT}_{50}$ 농도 의 $\mathrm{LA}$ 를 배양 세포에 처리하기 전에 $\mathrm{EH}$ 추출물이 각각 70 $\mu \mathrm{g} / \mathrm{mL}$ 와 $100 \mu \mathrm{g} / \mathrm{mL}$ 의 농도로 포함된 배양액에서 2 시간 동안 전 처리한 다음 이를 다시 XTT50 농도의 LA로 72시간 동안 처리 후 세포 생존율측정법에 의하여 LA만의 처리와 비교 조사하였다.

\section{8. 세포 생존율(cell viability) 측정}

약제의 독성이나 추출물의 효과 판정을 위하여 Mosmann [18]의 방법에 따라 대조군을 포함한 약제나 추출물을 처리한 세포에 제조한 XTT, $50 \mathrm{mg} / \mathrm{mL}$ 를 배양 용기당 $10 \mu \mathrm{L}$ 씩 넣고 4 시간 동안 정치하였다. 정치 완료 후 배양액을 버린 다음 well당 $20 \mu \mathrm{L}$ 의 DMSO를 넣은 다음, ELISA reader (Spectra max 250, Molecular Devices, Sunnyvale, USA)에서 아무 것도 넣지 않 은 blank, 세포없이 배양액만 넣은 0 , 세포에 약제를 처리하지 않은 대조군 및 약제 및 추출물을 처리한 실험군을 각각 선택 후 $450 \mathrm{~nm}$ 에서 흡광도를 측정하여 blank와 0 값을 보정한 대조군 과 비교 조사하였다. 회귀직선식(regressive equation)에 의하 여 $\mathrm{XTT}_{90}$ 과 $\mathrm{XTT}_{50}$ 을 산출하였다.

\section{9. 지질과산화(lipidperoxidation, LP) 측정}

LP 측정은 Kikuzaki과 Nakatani [19]의 방법에 따라 측정하 였다. 즉, 시료 $3.9 \mathrm{~mL}$ 와 에탄올을 혼합한 후 에탄올에 녹인 $2.52 \%$ linoleic acid와 0.05 M phosphate buffer ( $\mathrm{pH}$ 7.0)를 혼합액 $12.1 \mathrm{~mL}$ 를 첨가하여 $40^{\circ} \mathrm{C}$ 에서 24 시간 동안 배양하였 다. 배양 완료 후 이 반응액 $0.1 \mathrm{~mL}$ 에 에탄올과 $30 \% \mathrm{ammonium}$ thiocyanate 혼합액 $9.8 \mathrm{~mL}$ 를 혼합하고 여기에 $0.02 \mathrm{M}$ ferrous chloride $0.1 \mathrm{~mL}$ 를 넣고 실온에서 3 분간 정치하였다. 정치 후 ELISA reader로 $500 \mathrm{~nm}$ 에서 흡광도를 측정하였다. LP 
저해능은 시료첨가군과 무첨가군의 차이에 의한 백분율로 표시 하였으며, vitamin E 활성을 양성대조군으로 하여 비교 조사하 였다.

\section{SOD-유사활성 분석}

SOD-유사활성 측정은 Marklund와 Marklund [20]의 방법 에 따라, 시료에 $0.2 \mathrm{~mL}$ 에 Tris-HCl buffer와 $10 \mathrm{mM}$ pyrogallol 혼합액 $3.2 \mathrm{~mL}$ 를 넣은 다음 $25^{\circ} \mathrm{C}$ 에서 10 분 동안 처리하 였다. 처리 완료 후 $1 \mathrm{~N} \mathrm{HCl} 1 \mathrm{~mL}$ 로 반응시킨 다음 ELISA reader로 $420 \mathrm{~nm}$ 에서 흡광도를 측정하였다. SOD-유사활성 능은 시료첨가군과 무첨가군의 차이에 의한 백분율로 표시하였 으며 vitamin $\mathrm{E}$ 의 활성을 양성대조군으로 하여 비교 조사하였다.

\section{DPPH-radical 소거능 측정}

DPPH-radical 소거능은 Blois [21]의 방법에 따라 메탄올에 녹인 농도별 시료에 $0.3 \mathrm{mM} \mathrm{DPPH}$ 메탄올용액 $100 \mu \mathrm{L}$ 를 넣고 실온에서 30 분 동안 반응시켰다. 반응 완료 후 ELISA reader로 $517 \mathrm{~nm}$ 에서 흡광도를 측정하였다. 소거능은 시료첨가군과 무 첨가군간의 차이를 시료무첨가군에 의한 백분율로 나타냈으 며, 또한 vitamin E의 활성을 양성대조군으로 하여 비교 조사하 였다.

\section{2. 총 폴리페놀(polyphenol) 및 총 플라보노이드(flavonoid) 함량 측정}

총 폴리페놀의 함량 측정은 Folin-Denis [22] 방법에 의하여 시료, $1 \mathrm{~mL}$ 에 $1 \mathrm{~mL}$ 의 Folin 시약을 가한 후, 3 분간 정치하고 $10 \% \mathrm{Na}_{2} \mathrm{CO}_{3} 1 \mathrm{~mL}$ 를 넣어 1시간 동안 반응시켰다. 반응 완료 후 ELISA reader로 $725 \mathrm{~nm}$ 에서 흡광도를 측정하였으며 검량 곡선은 tannic acid를 이용하여 작성하였다. 총 플라보노이드 함량 측정은 Davies 변법[23]에 따라 시료 $0.1 \mathrm{~mL}$ 에 diethylene glycol $1 \mathrm{~mL}$ 와 $1 \mathrm{~N} \mathrm{NaOH} 0.1 \mathrm{~mL}$ 를 가하여 $37^{\circ} \mathrm{C}$ 항온수

Table 1. The cell viability of LA on cultured C6 glioma cells

\begin{tabular}{lllll}
\hline \multirow{2}{*}{$\begin{array}{c}\text { Concentrations } \\
\text { of LA }(\mu \mathrm{M})\end{array}$} & $\begin{array}{c}\text { XTT assay } \\
(450 \mathrm{~nm})\end{array}$ & $F$ & $P$ & Tukey HSD \\
\cline { 2 - 2 } & Mean $\pm \mathrm{SD}$ & & & \\
\hline Control $^{\mathrm{a}}$ & $0.31 \pm 0.02$ & 26.25 & $<.001$ & $\mathrm{a}, \mathrm{b}>\mathrm{e}, \mathrm{c}>\mathrm{d}$ \\
$5^{\mathrm{b}}$ & $0.29 \pm 0.01$ & & & \\
$10^{\mathrm{c}}$ & $0.27 \pm 0.01$ & & & \\
$20^{\mathrm{d}}$ & $0.25 \pm 0.01$ & & & \\
$\mathrm{XTT}_{90}(\mathrm{LA})^{\mathrm{e}}$ & $0.28 \pm 0.01$ & & & \\
\hline
\end{tabular}

The data indicate the mean \pm SD for triplicate experiments. Abbreviation: LA, lead acetate.
조에서 1시간 동안 반응시킨 후, ELISA reader로 $420 \mathrm{~nm}$ 에서 흡광도를 측정하였으며, 검량 곡선은 rutin을 이용하여 작성하 였다.

\section{3. 세포의 형태적 관찰}

배양 세포에 XTT $5_{50}$ 농도의 LA나 EH 추출물 $100 \mu \mathrm{g} / \mathrm{mL}$ 를 각 각 72시간 동안 처리 또는 2시간 동안 전 처리한 후에 이에 대한 세포의 형태적 변화를 위상차현미경(TE-2000, Japan)으로 관 찰하였다.

\section{4. 통계 처리}

실험의 모든 자료는 3 회 이상 반복한 결과를 mean $\pm \mathrm{SD}$ 로 나 타냈으며, 통계는 SPSS (Win Version 18.0, SPSS Inc., Chicago, IL, USA)를 이용하여 군간의 차이를 비교하기 위하여 ANOVA를 시행하였다. 사후 분석은 Tukey's HSD (honest significant difference)로 하였으며, 모든 통계의 유의 수준은 $P<0.05$ 의 경우를 유의한 것으로 채택하였다.

\section{결 과}

\section{1. $\mathrm{LA}$ 의 신경독성 $(\mathrm{XTT} 90)$ 측정}

$\mathrm{LA}_{\mathrm{A}}$ 의 XT90 (lower-toxicity) 농도를 측정하기 위하여 LA가 $0,5,10,20 \mu \mathrm{M}$ 의 농도로 각각 포함된 배양액에서 세포를 처리 한 결과 $5 \mu \mathrm{M}$ 의 처리에서는 세포 생존율이 대조군

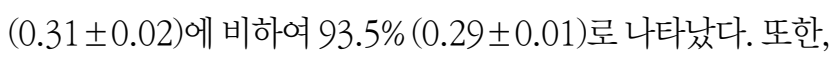
$10 \mu \mathrm{M}$ 의 처리에서는 $87.1 \%(0.27 \pm 0.01)$ 로 나타났으며, 20 $\mu \mathrm{M}$ 의 처리에서는 $80.6 \%(0.25 \pm 0.01)$ 로 나타났다 $(P<0.001)$. 이 과정에서 $\mathrm{XTT}_{90}$ 농도는 $7.5 \mu \mathrm{M}$ 에서 나타났다(Table 1). 세 포 생존율에 대한 사후 분석 결과 대조군과 $5 \mu \mathrm{M}, \mathrm{XTT}_{90}$ 과 10 $\mu \mathrm{M}$ 과 $20 \mu \mathrm{M}$ 순으로 세포 생존율이 높음을 알 수 있었다.

Table 2. The cell viability of LA on cultured C6 glioma cells

\begin{tabular}{|c|c|c|c|c|}
\hline \multirow{2}{*}{$\begin{array}{c}\text { Concentrations } \\
\text { of } L A(\mu M)\end{array}$} & $\begin{array}{l}\text { XTT assay } \\
(450 \mathrm{~nm})\end{array}$ & \multirow[t]{2}{*}{$F$} & \multirow[t]{2}{*}{$P$} & \multirow[t]{2}{*}{ Tukey HSD } \\
\hline & Mean士SD & & & \\
\hline Control $^{\mathrm{a}}$ & $0.36 \pm 0.03$ & 112.86 & $<0.001$ & $a>b>e, c>d$ \\
\hline $30^{\mathrm{b}}$ & $0.24 \pm 0.02$ & & & \\
\hline $40^{c}$ & $0.17 \pm 0.02$ & & & \\
\hline $50^{d}$ & $0.14 \pm 0.02$ & & & \\
\hline $\mathrm{XTT}_{50}(\mathrm{LA})^{\mathrm{e}}$ & $0.18 \pm 0.02$ & & & \\
\hline
\end{tabular}

The data indicate the mean \pm SD for triplicate experiments. Abbreviation: See Table 1. 


\section{2. $\mathrm{LA}$ 의 신경독성 $\left(\mathrm{XTT}_{50}\right)$ 측정}

$\mathrm{LA}$ 의 XTT $\mathrm{X}_{50}$ (higher-toxicity) 농도를 측정하기 위하여 LA 가 $30,40,50 \mu \mathrm{M}$ 의 농도로 각각 포함된 배양액에서 세포를 처

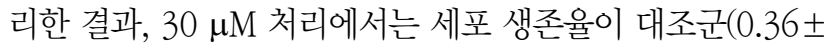
$0.03)$ 에 비하여 $66.7 \%(0.24 \pm 0.02)$ 로 나타났다 $(P<0.001)$. $40 \mu \mathrm{M}$ 의 처리에서는 $47.2 \%$ (0.17 \pm 0.02$)$ 로 나타났으며, 50 $\mu \mathrm{M}$ 처리에서는 $38.9 \%(0.14 \pm 0.02)$ 로 나타났다 $(P<0.001)$. 또한 이 과정에서 $\mathrm{XTT}_{50}$ 농도는 $38.6 \mu \mathrm{M}$ 에서 나타났다(Table 2, Figure 1). 세포 생존율에 대한 사후 분석 결과, 대조군, 30 $\mu \mathrm{M}, \mathrm{XTT}_{50}$ 과 $40 \mu \mathrm{M}, 50 \mu \mathrm{M}$ 순으로 세포 생존율이 높음을 알수 있었다.

\section{3. $\mathrm{LA}$ 의 신경 독성에 대한 비타민 $\mathrm{E}$ 의 영향}

$\mathrm{LA}$ 의 신경 독성에 대한 비타민 $\mathrm{E}$ 의 영향을 알아보기 위하여 $\mathrm{XTT}_{50}$ 농도의 LA를 배양 세포에 처리하기 전에 비타민 E가 30 $\mu \mathrm{M}$ 과 $40 \mu \mathrm{M}$ 로 각각 포함된 배양액에서 2시간 동안 처리한 결 과, LA만의 처리에서는 세포 생존율이 대조군에 비하여 $47.6 \%$

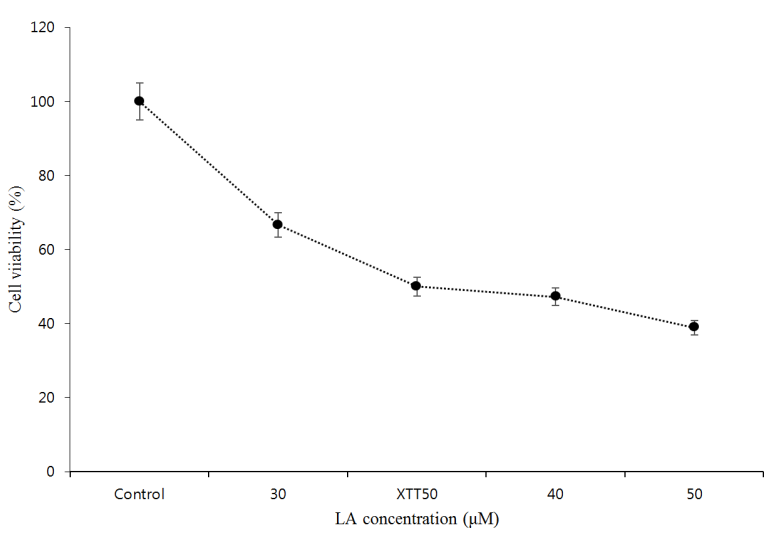

Figure 1. The cytotoxicity of LA at the concentrations of 30,40 and $50 \mu \mathrm{M}$ in cultured C6 glioma cells. Cell viability was measured by XTT assay. Significantly different from control.

Table 3. The effect of vitamin $E$ on the LA-induced cytotoxicity in cultured $\mathrm{C} 6$ glioma cells

\begin{tabular}{llllll}
\hline \multirow{2}{*}{$\begin{array}{c}\text { Concentrations of } \\
\text { vitamin } E(\mu \mathrm{M})\end{array}$} & $\begin{array}{c}\text { XTT assay } \\
(450 \mathrm{~nm})\end{array}$ & $F$ & $P$ & Tukey HSD \\
\cline { 2 - 2 } & Mean \pm SD & & & \\
\hline Control $^{\mathrm{a}}$ & $0.42 \pm 0.05$ & 60.10 & $<0.001$ & $\mathrm{a}>\mathrm{d}, \mathrm{c}>\mathrm{b}$ \\
$\mathrm{LA}^{\left(X_{T} T_{50}\right)^{\mathrm{b}}}$ & $0.20 \pm 0.02$ & & & \\
$30^{\mathrm{c}}$ & $0.28 \pm 0.02$ & & & \\
$40^{\mathrm{d}}$ & $0.32 \pm 0.03$ & & & \\
\hline
\end{tabular}

The data indicate the mean \pm SD for triplicate experiments. Abbreviation: See Table 1.
$(0.20 \pm 0.02)$ 로 나타난 반면, $30 \mu \mathrm{M}$ 비타민 $\mathrm{E}$ 의 처리에서는

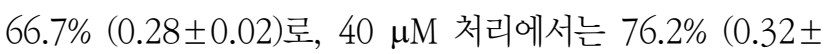
0.03)로 나타났다 $(P<0.001)$ (Table 3). LA에 대한 비타민 E의 세포 생존율에 대한 사후 분석 결과, 대조군, $40 \mu \mathrm{M}$ 과 $30 \mu \mathrm{M}$, $\mathrm{XTT}_{50}$ 순으로 세포 생존율이 높음을 알 수 있었다.

\section{4. $\mathrm{EH}$ 추출물의 세포독성}

$\mathrm{EH}$ 추출물의 세포독성을 조사하기 위하여 $\mathrm{EH}$ 추출물이 각각 10 130 $\mu \mathrm{g} / \mathrm{mL}$ 로 포함된 배양액에서 세포를 처리한 결과, 10 $\mu \mathrm{g} / \mathrm{mL}(116.7 \%, 0.49 \pm 0.02)$ 와 $40 \mu \mathrm{g} / \mathrm{mL}(102.4 \%, 0.43 \pm 0.03)$ 의 $\mathrm{EH}$ 추출물 처리에서는 세포 생존율이 대조군 $100 \%$ (0.42 \pm 0.03$)$ 에 비하여 증가하였다. 또한, $70 \mu \mathrm{g} / \mathrm{mL}(97.6 \%$, $0.41 \pm 0.02)$ 와 $100 \mu \mathrm{g} / \mathrm{mL}(92.9 \%, 0.39 \pm 0.02), 130 \mu \mathrm{g} / \mathrm{mL}$ $(88.1 \%, 0.37 \pm 0.01)$ 의 추출물 처리에서는 세포 생존율이 점차 감소되어 $100 \mu \mathrm{g} / \mathrm{mL}$ 에서 최대허용농도를 나타냈다. 따라서 $100 \mu \mathrm{g} / \mathrm{mL}$ 이하 농도에 해당되는 $70 \mu \mathrm{g} / \mathrm{mL}$ 와 $100 \mu \mathrm{g} / \mathrm{mL}$ 를 실험 농도로 정하였다(Figure 2).

\section{5. $\mathrm{LA}$ 의 신경 독성에 대한 $\mathrm{EH}$ 추출물의 영향}

$\mathrm{LA}$ 의 신경 독성에 대한 $\mathrm{EH}$ 추출물의 영향을 알아본 결과, $\mathrm{XTT}_{50}$ 농도인 LA만의 처리에서는 세포 생존율이 $47.1 \%$ $(0.16 \pm 0.02)$ 로 나타난 반면, $70 \mu \mathrm{g} / \mathrm{mL}$ 의 EH 추출물 처리에서 는 $67.6 \%(0.23 \pm 0.02)$ 로 나타났다. 또한, $100 \mu \mathrm{g} / \mathrm{mL}$ 의 EH 추

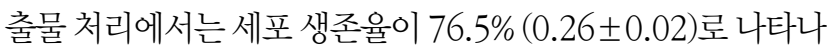
통계적으로 유의한 차이를 보였다 $(P<0.001)$ (Table 4). LA의 신경 독성과 $\mathrm{EH}$ 추출물의 영향에 따른 사후 검정결과, 대조군, $100 \mu \mathrm{g} / \mathrm{mL}$ 의 EH 추출물과 $70 \mu \mathrm{g} / \mathrm{mL}$ EH 추출물과 $\mathrm{XTT}_{50}$

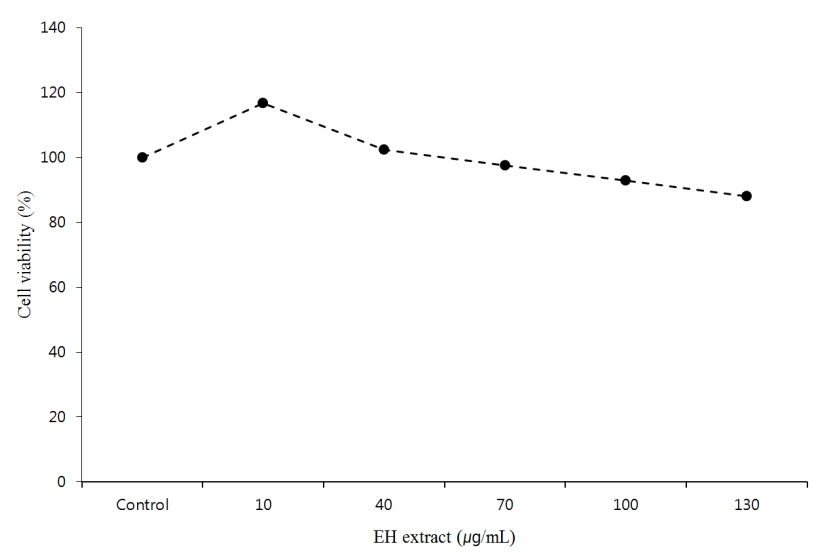

Figure 2. C6 glioma cells were treated with $\mathrm{EH}$ extract at the concentrations of $10,40,70,100$ and $130 \mu \mathrm{g} / \mathrm{mL}$, respectively. The data indicate the mean \pm SD for triplicate experiments. Significantly different from control. 
Table 4. The effect of EH extract on the LA-induced cytotoxicity in cultured C6 glioma cells

\begin{tabular}{cccccc}
\hline Concentrations of & $\begin{array}{c}\text { XTT assay } \\
(450 \mathrm{~nm})\end{array}$ & $F$ & $P$ & Tukey HSD \\
EH extract $(\mu \mathrm{g} / \mathrm{mL})$ & $\begin{array}{ccccc}\text { Mean } \pm \text { SD } \\
\end{array}$ & & & \\
\hline Control $^{\mathrm{a}}$ & $0.34 \pm 0.03$ & 70.12 & $<0.001$ & $\mathrm{a}>\mathrm{d}, \mathrm{c}>\mathrm{b}$ \\
$\mathrm{XTT}_{50}(\mathrm{LA})^{\mathrm{b}}$ & $0.16 \pm 0.02$ & & & \\
$70^{\mathrm{c}}$ & $0.23 \pm 0.02$ & & & \\
$100^{\mathrm{d}}$ & $0.26 \pm 0.02$ & & & \\
\hline
\end{tabular}

The data indicate the mean \pm SD for triplicate experiments. Abbreviation: EH, Euphorbiae humifusae L.; See Table 1.

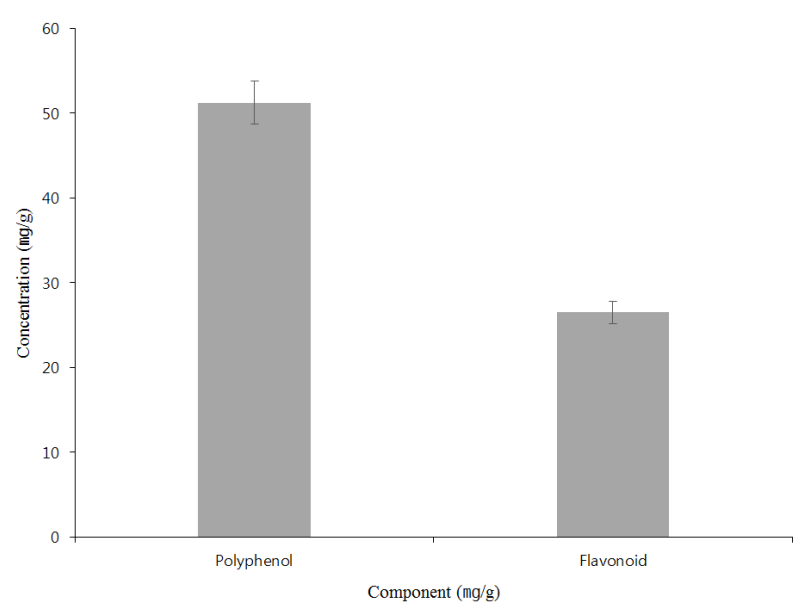

Figure 3. Total amount of polyphenol and flavonoid of Euphorbiae humifusae $\mathrm{L}$. $(\mathrm{EH})$ extract. The data indicate the mean \pm SD for triplicate experiments.

(LA)순으로 세포 생존율이 높게 나타났다.

\section{EH 추출물의 총 폴리페놀(polyphenol) 및 총 플라보노이드 (flavonoid) 함량 측정}

$\mathrm{EH}$ 추출물에 대한 함량분석에서 총 폴리페놀의 함량은 51.2 $\mathrm{mg} / \mathrm{g}$, 총 플라보노이드 함량은 $26.5 \mathrm{mg} / \mathrm{g}$ 로 나타났다(Figure 3).

\section{7. 지질과산화(lipid peroxidation, LP) 측정}

$\mathrm{EH}$ 추출물이 LP에 미치는 영향을 조사하기 위하여 $\mathrm{EH}$ 추출물 시료 $70 \mu \mathrm{g} / \mathrm{mL}$ 의 처리에서는 대조군에 비하여 LP가 $75.0 \%$ (0.18 \pm 0.02$)$ 로, $100 \mu \mathrm{g} / \mathrm{mL}$ 의 처리에서는 $75.0 \%(0.18 \pm 0.02)$ 로 나타났다. 또한, 양성 대조군인 $40 \mu \mathrm{M}$ 비타민 $\mathrm{E}$ 처리군에서는 $20.8 \%(0.05 \pm 0.01)$ 로 나타났다. 따라서, LP 억제능은 70 $\mu \mathrm{g} / \mathrm{mL}$ 의 EH 추출물(25.0\%), $100 \mu \mathrm{g} / \mathrm{mL}$ 의 EH 추출물(25.0\%), $40 \mu \mathrm{M}$ 의 비타민 $\mathrm{E}(79.2 \%)$ 로 나타나 모두 대조군에 비하여 유의 한 증가를 보였다 $(P<0.001)$ (Table 5, Figure 4). $\mathrm{EH}$ 추출물의 $\mathrm{LP}$ 억제능에 대한 사후검정 결과, $40 \mu \mathrm{M}$ 비타민 $\mathrm{E}, 100 \mu \mathrm{g} / \mathrm{mL}$
Table 5. The effect of EH extract on LP

\begin{tabular}{llllll}
\hline \multirow{2}{*}{$\begin{array}{c}\text { Concentrations of } \\
\text { EH extract }(\mu \mathrm{g} / \mathrm{mL})\end{array}$} & $\begin{array}{l}\mathrm{LP}(500 \mathrm{~nm}) \\
\end{array}$ & $F$ & $P$ & Tukey HSD \\
\hline Control $^{\mathrm{a}}$ & $0.24 \pm 0.02$ & 150.59 & $<0.001$ & $\mathrm{a}<\mathrm{d}, \mathrm{c}<\mathrm{b}$ \\
$40 \mu \mathrm{M}$ vitamin $\mathrm{E}^{\mathrm{b}}$ & $0.05 \pm 0.01$ & & & \\
$70^{\mathrm{c}}$ & $0.18 \pm 0.02$ & & & \\
$100^{\mathrm{d}}$ & $0.18 \pm 0.02$ & &
\end{tabular}

The data indicate the mean \pm SD for triplicate experiments. Vitamin $\mathrm{E}$ was used as positive control.

Abbreviation: EH, Euphorbiae humifusae L.; LP, lipid peroxidation.

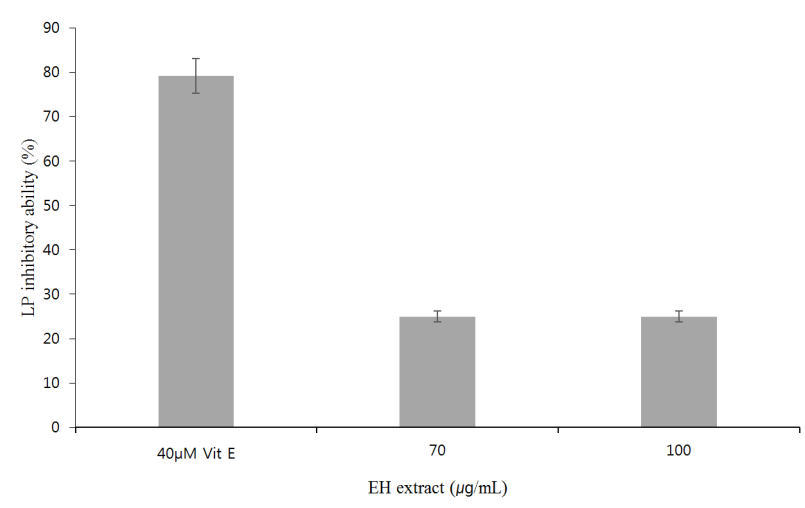

Figure 4. The inhibitory effect of Euphorbiae humifusae L. (EH) extract on LP. The data indicate the mean \pm SD for triplicate experiments. Significantly different from control.

$\mathrm{EH}$ 추출물과 $70 \mu \mathrm{g} / \mathrm{mL} \mathrm{EH}$ 추출물과 대조군 순으로 억제능이 높게 나타났다.

\section{SOD-유사 활성(superoxide dismutase like activity, SLA) 측정}

$\mathrm{EH}$ 추출물 시료에 대한 $\mathrm{SOD}$-유사활성을 알아보기 위하여 $70 \mu \mathrm{g} / \mathrm{mL}$ 와 $100 \mu \mathrm{g} / \mathrm{mL}$ 의 EH 추출물에 대하여 조사한 결과, $70 \mu \mathrm{g} / \mathrm{mL}$ 의 EH 추출물 처리에서는 대조군에 비하여 $116.7 \%$ (0.21 \pm 0.04$)$ 로, $100 \mu \mathrm{g} / \mathrm{mL}$ 의 EH 추출물 처리에서는 $127.8 \%$ $(0.23 \pm 0.02)$ 의 유사활성을 나타냈다. 또한, $40 \mu \mathrm{M}$ 비타민 E에 서는 $133.3 \%$ (0.24 \pm 0.02$)$ 의 유사활성을 보였다. 따라서 유사 활성능은 $70 \mu \mathrm{g} / \mathrm{mL}$ 의 EH추출물(16.7\%), $100 \mu \mathrm{g} / \mathrm{mL}$ 의 EH 추 출물(27.8\%), $40 \mu \mathrm{M}$ 의 비타민 $\mathrm{E}(33.3 \%)$ 에서 대조군에 비하여 유의한 증가를 보였다 ( $P=0.001$ ) (Table 6, Figure 5). EH 추출 물의 SOD-유사활성능에 대한 사후검정 결과, $40 \mu \mathrm{M}$ 비타민 $\mathrm{E}$ 와 $100 \mu \mathrm{g} / \mathrm{mL}$ 의 EH 추출물은 통계적으로 차이가 없으나 대조 군에 비해 높게 나타났다. $70 \mu \mathrm{g} / \mathrm{mL} \mathrm{EH}$ 추출물은 대조군과 40 $\mu \mathrm{M}$ 의 비타민 $\mathrm{E}, 100 \mu \mathrm{g} / \mathrm{mL}$ 의 $\mathrm{EH}$ 추출물과 통계적인 차이가 없었으나 대조군보다는 SOD-유사활성능이 다소 높았다. 


\section{DPPH (1,1-diphenyl-2-picrylhydrazyl)-라디컬 소거능 (radical scavenging activity, DRSA) 측정}

$\mathrm{EH}$ 추출물 시료에 대한 DPPH-radical 소거 활성을 조사한 결과, $70 \mu \mathrm{g} / \mathrm{mL}$ 의 $\mathrm{EH}$ 추출물 처리에서는 소거 활성이 $82.1 \%$ $(0.23 \pm 0.02)$ 로 나타났으며, $100 \mu \mathrm{g} / \mathrm{mL}$ 의 $\mathrm{EH}$ 추출물 처리에

Table 6. The SLA of EH extract

\begin{tabular}{|c|c|c|c|c|}
\hline \multicolumn{2}{|c|}{ Concentrations of SLA $(420 \mathrm{~nm})$} & \multirow{2}{*}{$\mathrm{F}$} & \multirow{2}{*}{$P$} & \multirow{2}{*}{ Tukey HSD } \\
\hline$(\mu \mathrm{g} / \mathrm{mL})$ & Mean $\pm S D$ & & & \\
\hline Control $^{\mathrm{a}}$ & $0.18 \pm 0.02$ & 7.05 & 0.001 & $b, d>a$ \\
\hline $40 \mu \mathrm{M}$ vitamin $\mathrm{E}^{\mathrm{b}}$ & $0.24 \pm 0.02$ & & & \\
\hline $70^{c}$ & $0.21 \pm 0.04$ & & & \\
\hline $100^{d}$ & $0.23 \pm 0.02$ & & & \\
\hline
\end{tabular}

The data indicate the mean \pm SD for triplicate experiments. Vitamin E was used as positive control.

Abbreviations: EH, Euphorbiae humifusae L.; SLA, superoxide dismutase like activity.

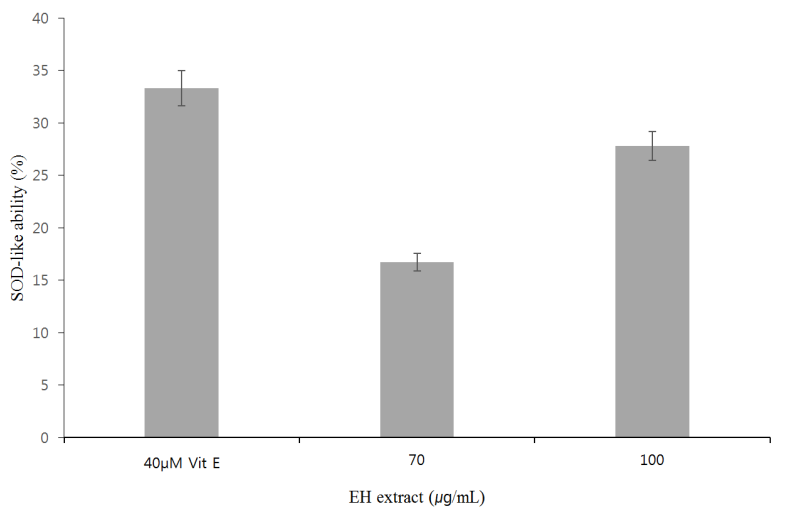

Figure 5. The SOD-like ability of Euphorbiae humifusae (EH) L. extract. The data indicate the mean \pm SD for triplicate experiments. Significantly different from control.
서는 $71.4 \%(0.20 \pm 0.02)$ 로 나타났다. 또한 $40 \mu \mathrm{M}$ 의 비타민 $\mathrm{E}$ 처리에서는 $28.6 \%(0.08 \pm 0.01)$ 로 나타났다. 따라서, $\mathrm{EH}$ 추출 물 $70 \mu \mathrm{g} / \mathrm{mL}$ (17.9\%)와 $100 \mu \mathrm{g} / \mathrm{mL}(28.6 \%)$, 비타민 E $40 \mu \mathrm{M}$ (71.4\%)의 DPPH-radical 소거능은 대조군에 비하여 통계적으 로 유의하였다 $(P<0.001)$ (Table 7, Figure 6). DPPH-radical

Table 7. The DRSA of EH extract

\begin{tabular}{llllll}
\hline \multirow{2}{*}{$\begin{array}{c}\text { Concentrations of } \\
\text { EH extract }(\mu \mathrm{g} / \mathrm{mL})\end{array}$} & Mean \pm SD & & & $P$ & Tukey HSD \\
\hline Control & $0.28 \pm 0.01$ & 171.08 & $<0.001$ & $\mathrm{~b}>\mathrm{c}>\mathrm{a}$ \\
$40 \mu \mathrm{M}$ vitamin $\mathrm{E}^{\mathrm{a}}$ & $0.08 \pm 0.01$ & & & \\
$70^{\mathrm{b}}$ & $0.23 \pm 0.02$ & & & \\
$100^{\mathrm{c}}$ & $0.20 \pm 0.02$ & & & \\
\hline
\end{tabular}

The data indicate the mean \pm SD for triplicate experiments. Vitamin $\mathrm{E}$ was used as positive control.

Abbreviations: DRSA, DPPH-radical scavenging activity; EH, Euphorbiae humifusae L.

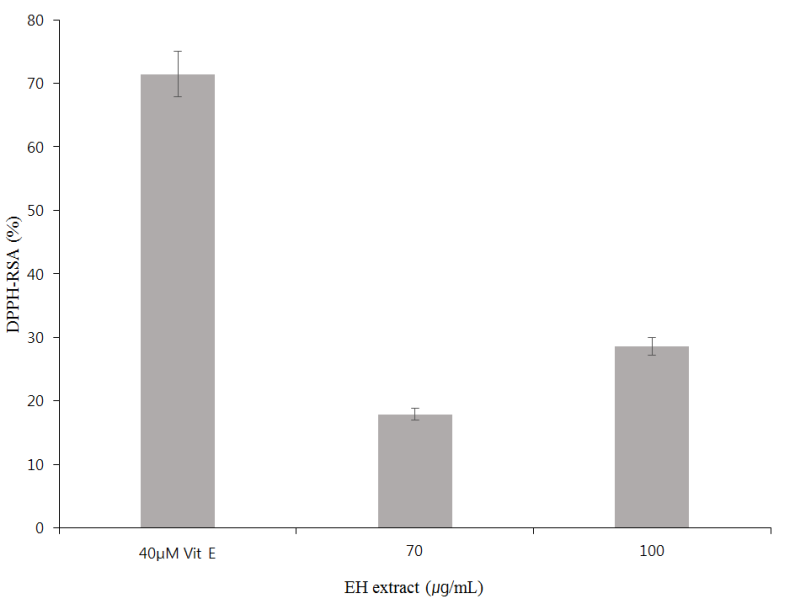

Figure 6. The DPPH-radical scavenging ability (DPPH-RSA) of Euphorbiae humifusae L. (EH).

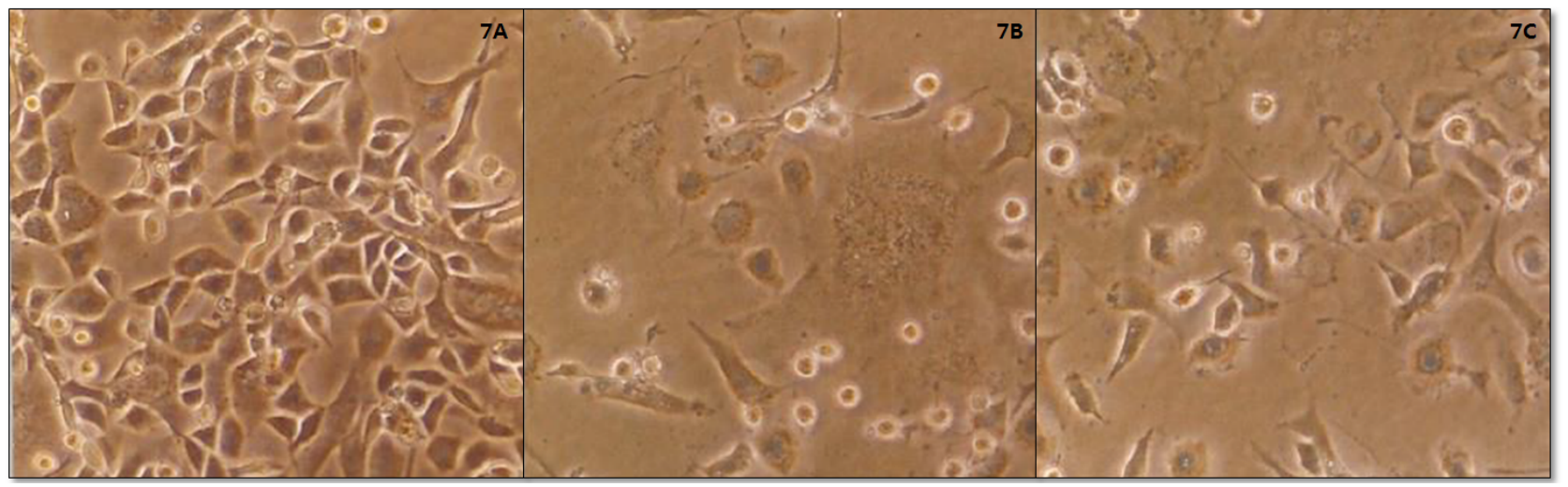

Figure 7. Effect of LA or EH extract on cultured C6 glioma cells $(A \sim C)$. The photographs of inverted microscope at $\times 200$. 
소거능의 사후검정 결과, $70 \mu \mathrm{g} / \mathrm{mL}$ EH 추출물, $100 \mu \mathrm{g} / \mathrm{mL} \mathrm{EH}$ 추출물, 비타민 E $40 \mu \mathrm{M}$ 순으로 높은 것으로 나타났다.

\section{0. 세포의 형태적 관찰}

약제를 처리하지 않은 대조군에서는 많은 세포들이 밀접하 게 붙어 있었으며 짧은 돌기로 세포간 연결이 잘 되어 있었다 (Figure 7A). 반면, $\mathrm{XTT}_{50}$ 농도의 LA 추출물의 처리에 있어서는 손상 받지 않은 세포들은 더 길다란 돌기로 서로 연결하고 있는 것에 비하여 일부 손상을 받은 세포들은 세포간 돌기의 소실로 인해 서로간 연결이 잘 이루어지지 않았으며, 세포체의 퇴화 현 상도 관찰되었다(Figure 7B). 한편, $100 \mu \mathrm{g} / \mathrm{mL}$ 의 $\mathrm{EH}$ 추출물의 전 처리에서는 LA 처리군에 비하여 수적으로 많은 세포들이 돌 기에 의해 비교적 잘 연결되어 있었으며, 대조군과 유사한 양상 을 보였다(Figure 7C).

\section{고 찰}

납은 환경오염원인 동시에 돌연변이원으로 독성이 매우 강 하기 때문에 납이 인체 내에 폭로되면 중독을 일으켜 각종 질병 을 유발하게 된다[24]. 특히, 납은 혈액-뇌 관문(blood-brain barrier, BBB)을 통과하여 뇌중독을 유발함으로서 이의 독성은 관심의 대상이 되었다[3]. 본 연구에서는 납의 일종인 초산납 (LA)에 대한 신경독성을 조사하기 위하여 XTT90 (저독성)과 치 사농도 50 (lethal concentration 50, $\mathrm{LC}_{50}$ )인 XTT50 (고독성) 을 측정하였다. 이를 위해 대뇌신경교세포주인 C6 glioma 세포 를 LA가 0 50 $\mu \mathrm{M}$ 농도로 각각 포함된 배양액에서 처리한 결과, 처리 농도에 의존적으로 세포 생존율이 대조군에 비하여 유의 하게 감소됨으로서 세포독성을 나타냈다. 이 과정에서 $\mathrm{XTT}_{90}$ 과 $\mathrm{XTT}_{50}$ 이 각각 $7.5 \mu \mathrm{M}$ 과 $38.6 \mu \mathrm{M}$ 로 나타났으며, 특히, $\mathrm{XTT}_{50}$ 이 $100 \mu \mathrm{M}$ 이하인 $38.6 \mu \mathrm{M}$ 로 나타나 고독성 (highly-toxic)인 것으로 확인되었다[21]. 본 연구 결과는 LA $\mathrm{XTT}_{50}$ 값이 배양 $\mathrm{NIH} 3 \mathrm{~T} 3$ 섬유모세포에서 $48.3 \mu \mathrm{M}$ [5], 배양 C6 glioma 세포에서 $33.3 \mu \mathrm{M}$ [4]로 나타났다는 연구 보고와 함 께 LA가 세포에 고독성인 것을 알 수 있었다. 이 현상은 본 연구 의 세포의 형태적 관찰과도 일치함으로서 이를 증명하고 있다. 본 연구에서처럼 LA가 배양 C6 glioma 세포에 독성을 나타낸 것은 세포내 칼슘 채널을 봉쇄하여 대사를 억제하였거나 단백 질합성저해나 DNA와 같은 핵산 물질의 저해와 같은 여러 요인 도 있겠지만[26], 그 보다는 LA의 산화적 손상에 기인한 결과일 가능성을 배제할 수 없다. 따라서, 본 연구에서는 LA의 신경 독 성과 산화적 손상 간의 연관성을 알아보기 위하여 항산화제의
일종인 vitamin E $30 \mu \mathrm{M}$ 과 $40 \mu \mathrm{M}$ 농도 각각을 배양 세포에 전 처리 한 결과, LA만을 처리한 실험군에 비하여 vitamin E 처리 군에서 모두 유의한 세포 생존율의 증가를 나타냈다. 본 결과는 항산화제인 vitamin E가 LA의 독성을 방어한 것으로서 이는 산 화적 손상이 LA독성과 관련이 있음을 제시하고 있다. 이 증거의 하나로서 산화적 손상과 관련이 깊은 $\mathrm{NMDA}$ 수용체 길항제가 $\mathrm{LA}$ 의 독성을 방어하였다는 연구 결과가 이를 뒷받침 해 준다 [4].

한편, 대극과에 속하는 지금초(Euphorbiae humifusae, $\mathrm{L} . \mathrm{EH})$ 추출물이 LA 신경독성에 미치는 영향을 조사하기 위하여 $\mathrm{EH} 70 \mu \mathrm{g} / \mathrm{mL}$ (67.6\%)와 $100 \mu \mathrm{g} / \mathrm{mL}$ (76.5\%) 농도의 추출물을 배양 C6 glioma 세포에 전 처리한 결과, 추출물의 처리 농도에 비례하여 LA 처리군인 $47.1 \%$ 에 비하여 유의한 세포 생존율의 증가를 나타냈다. 이 같은 현상은 현미경적 관찰에서도 일치하 였다. 또한 조개나물 추출물 $90 \mu \mathrm{g} / \mathrm{mL}$ (75.0\%) [27], 꽃향유 추 출물 $80 \mu \mathrm{g} / \mathrm{mL}$ (61.6\%) [18] 보다 더 높은 세포 생존율을 나타 냈다. 본 결과는 $\mathrm{EH}$ 추출물이 LA의 독성으로부터 세포를 보호 한 것으로 LA에 의한 산화적 손상을 $\mathrm{EH}$ 추출물의 항산화능이 방어하여 세포 생존율을 증가시킨 것으로 생각된다. 이같은 현 상은 본 연구의 $\mathrm{EH}$ 추출물에 대한 성분함량분석 측정에서 폴리 페놀과 플라보노이드 성분이 함유되어 있는 것으로 보아 flavonol이나 quercetin과 같은 플라보노이드 성분이나 gallic $\mathrm{acid}$ 와 같은 폴리페놀 성분에 기인한 것으로 생각된다[14]. 또 한 질산납 $\left[\mathrm{Pb}\left(\mathrm{NO}_{3}\right)_{2}\right]$ 의 독성을 페놀화합물의 일종인 gallic $\mathrm{acid}$ 가 방어하였다는 연구 보고와 일치하였다[8]. 본 연구의 함 량조사에서 총 폴리페놀과 플라보노이드가 각각 $51.2 \mathrm{mg} / \mathrm{g}$ 과 $26.5 \mathrm{mg} / \mathrm{g}$ 으로 나타나, 항산화능이 강력한 삼백초 추출물의 $53.5 \mathrm{mg} / \mathrm{g}, 28.7 \mathrm{mg} / \mathrm{g}$ 과 거의 비슷한 것으로 나타났다[29].

따라서, 본 연구에서는 $\mathrm{EH}$ 추출물에 대한 $\mathrm{LP}$ 억제능, SOD유사활성능, 그리고 DPPH-radical 소거능으로 항산화작용을 분석하였다. 먼저 LP 조사에 있어서 $\mathrm{EH}$ 추출물은 대조군에 비 하여 유의한 LP 억제능을 나타냈다. 본 연구의 $\mathrm{EH}$ 추출물 100 $\mu \mathrm{g} / \mathrm{mL}$ 에서 LP 억제능이 $25 \%$ 로 나타났는데, 이는 조개 추출물 $90 \mu \mathrm{g} / \mathrm{mL}$ 에서 $28.6 \%$ 와 거의 비슷한 저해능을 보였다[27]. LP 는 세포막 대부분을 형성하고 있는 인지질이 자유라디칼에 의 하여 과산화 된 것으로, 세포 보호와 물질 수송에 손상을 주어 결 국 세포의 퇴화나 고사를 초래한다[30]. 한편, $\mathrm{EH}$ 추출물에 대 한 SOD-유사활성능 조사에서 $\mathrm{EH}$ 추출물은 대조군에 비해 높 은 유사활성능을 나타냈다. 본 연구는 $\mathrm{EH}$ 추출물의 $100 \mu \mathrm{g} / \mathrm{mL}$ 에서 SOD-유사 활성이 $27.8 \%$, 어성초 추출물의 $130 \mu \mathrm{g} / \mathrm{mL}$ 에 서 $25.4 \%$ 보다는 약간 높고[5], SOD-유사 활성이 높은 꽃향유 
추출물의 $80 \mu \mathrm{g} / \mathrm{mL}$ 에서 $28.4 \%$ 와 비슷한 활성을 나타냈다 [28]. SOD-유사활성능은 인체 내 항산화계에 속하는 SOD가 인체대사과정 중 형성되는 자유라디칼을 catalase와 함께 물로 변환시켜 주는 라디칼 제거능을 담당하고 있는데, $\mathrm{EH}$ 추출물이 이와 같은 기능이 있다는 것을 나타낸다[9]. 또한, DPPH-라디 칼 소거능 조사에 있어서는, $\mathrm{EH}$ 추출물은 대조군에 비하여 유의 한 DPPH-라디칼 소거능을 보임으로서 항산화능이 있음을 제 시하였다. 본 연구의 $\mathrm{EH}$ 추출물의 $100 \mu \mathrm{g} / \mathrm{mL}$ 에서 DPPH-radical 소거능은 $28.6 \%$ 로, 소거능이 높은 꽃향유 추출물 $60 \mu \mathrm{g} / \mathrm{mL}$ (50.7\%) [28]와 조개 나물 추출물 $80 \mu \mathrm{g} / \mathrm{mL}$ (60.9\%) [27]에 비 해 2배정도의 높은 소거능을 나타냈다. DPPH-라디칼 소거능 분석은 자유라디칼에 전자를 공유하는 능력을 측정하는 것으로 서 항산화능을 측정하는 대표적인 분석방법의 하나이다[31]. 위와 같은 LP를 비롯하여[32], 다양한 항산화 분석은 병변에 효 과적인 항산화 대체물질을 탐색 내지는 개발하는데 유용한 도 구로 활용되고 있다[33]. 이상의 결과로부터 LA는 C6 glioma 세포에서 강한 신경독성을 나타냈으며, 이같은 신경독성에 산 화적 손상이 관여하고 있음을 제시하였다. 또한, $\mathrm{EH}$ 추출물은 항산화능에 의하여 LA에 의한 신경독성을 유의하게 방어함으 로서 향후 $\mathrm{EH}$ 추출물과 같은 천연소재로부터 항산화 측면에서 새로운 치료적 대체물질을 개발하는데 있어 기초 자료로서의 활용도가 클 것으로 생각된다.

\section{요 약}

본 연구는 배양 C6 glioma 세포를 대상으로 초산납(lead acetate, LA)의 신경독성을 알아보았으며, 또한 LA의 세포독성 에 대한 지금초(Euphorbiae humifusae L., EH) 추출물의 영향 을 조사하였다. 본 연구에서, LA는 대조군에 비하여 농도 의존 적으로 세포 생존율이 감소됨으로서 신경독성을 보였으며, 0 $50 \mu \mathrm{M}$ 의 LA가 각각 포함된 배양액에서 72 시간 동안 세포를 처 리한 결과, $\mathrm{XTT}_{50}$ 값은 $38.6 \mu \mathrm{M}$ 로 고독성인 것으로 나타났다. 또한, 30 50 $\mu \mathrm{M}$ 의 LA가 각각 포함된 배양액에서 72시간 동안 세포를 처리한 결과 XTT 50 은 $38.6 \mu \mathrm{M}$ 에서 나타났다. 이와 동시 에 항산화제인 vitamin $\mathrm{E}$ 의 처리에서 LA 독성에 의하여 감소된 세포 생존율이 유의하게 증가함으로서 LA의 독성에 산화적 손 상이 관여하고 있음을 제시하였다. 한편, $\mathrm{EH}$ 추출물은 지질과 산화 저해능을 비롯하여 superoxide dismutase (SOD)-유사 활성능 및 DPPH-라디칼 소거능과 같은 항산화능에 의하여 LA 독성을 효과적으로 방어하였다. 이같은 항산화 효과는 gallic acid와 같은 폴리페놀이나 또는 flavonol이나 quercetin과 같
은 플라보노이드와 같은 항산화성분에 기인된 결과로 생각된 다. 결론적으로, $\mathrm{EH}$ 추출물과 같은 천연 소재는 차후 납신경독 성과 같이 산화적 손상과 관련된 질환 치료를 위한 유용한 활용 인자로 사료된다.

Acknowledgements: This paper was supported by Wonkwang Health Science University in 2018.

Conflict of interest: None

Author's information (Position): Lee SH${ }^{1}$, M.D.; Seo $\mathrm{YM}^{2}$,Professor.

\section{REFERENCES}

1. Lavid N, Schwartz A, Yarden O, Tel-Or E. The involvement of polyphenols and peroxidase avtivaties in heavy metal accumulation by epidermal glands of the waterlily (Nymphaeaceae). Planta. 2001;212:323-331. https://doi.org/10.1007/s004250000400.

2. Liu Y, Hsieh WC, Yang BC. In vitro aberrant gene expression as the indicator of lead-induced neurotoxicity in U-373 MG cells. Toxicol. 2000;147:59-64. https://doi.org/10.1016/S0300-483X (00)00186-4.

3. Verstraeten SV, Aimo L, Oteiza PI. Aluminum and lead molecular mechanisms of brain toxicity. Arc Toxicol. 2008;82: 789-802. https://doi.org/10.1007/s00204-008-0345-3.

4. Son YW, Lim YS, Seo YM. Protective effect of NMDA receptor antagonist on the neurotoxicity induced by lead as an environmental pollutant. J Kor Soc Occu Environ Hyg. 2017;27: 193-200. https://doi.org/10.15269/JKSOEH.2017.27.3.193.

5. Jung JY, Oh YH, Park SH, Yoo MY, Pyo AJ, et al. Antioxidative and whitening effects Houttuynia cordata extract on lead acetate of hair dye component. J Invest Cosm. 2014;10:99-105.

6. Aleksandra D, Jose LV, Ryota L, Mohammed KH, Sunniyat R, Alan B, Nabil H. PGC-1 $\alpha$ controls mitochondrial biogenesis and dynamics in lead-induced neurotoxicity. J Aging. 2015;7: 629-643.

7. Oh YH, Park ST. Protective effect of Prunella vulgaris L. var lilacina Nakai extract on cultured NIH3T3 fibroblasts damaged by mutagenic mercury-induced toxicity. J People Plants Environ. 2015;18:41-46.

8. Yoo SM, Back JC, Seo YM, Kim YS, Choi YJ. Effect of phenol compound on the cytotoxicity of heavy metal. J Life Natr Res. 2008;30:80-87.

9. Rosen D, Siddique T, Patterson D, Figlewiez D, Sapp P. Mutation in $\mathrm{Cu} / \mathrm{Zn}$ superoxide dismutase gene are associated with familial amyotrophic lateral sclerosis. Nature(London). 1993;362:59-62.

10. Ha DH, Yang HW, Lee JH, Lee KC. Effect of NMDA receptor antagonist on osteoblasts damaged by methylmercuric chloride. Kor J Oriental Physiol Pathol. 2003;17:412-415.

11. Gracia-Lopez D, Cuevas MJ, Almar M, Lima E. Paz JA, Gonzalez-Gallego J. Effects of eccentric exercise on NF-kB activation in blood monolayer cells. Med Sci Sports Exerc. 
2007;39:653-664.

12. Jung JY, Jung IJ, Jekal SJ. The protective effect of Lonicerae flos extraction on cultured C6 glioma cells damaged by aluminum of dementia inducer. Kor J Lab Sci. 2017;49:271-278. https://doi.org/10.15324/kjcls.2017.49.3.271.

13. Lee JM, Kim IC, Hur SS. Screening of antimicrobial activities of extracts from local some native plants against acnes strain. J Invest Cosm. 2013;9:379-387.

14. Fujisawa S, Kadoma Y. Anti- and pro-oxidant effects of oxidized quercetin curcumin-related compounds with thiols or ascorbate as measured by the induction period method. In Vitro. 2006;20:39-44.

15. Schwartz SM, Foy L, Bowen-Pope DF, Ross R. Derivation and properties of plate-derived growth factor-independent rat smooth muscle cells. Am J Pathol. 1990;136:1417-1428.

16. Lim KT Park ST, Cho MK, Chung YT. Neuronal cytotoxicity of oxygen radical in newborn mouse forebrain culture. Kor J Toxicol. 1995;11:187-192.

17. Chen YJ, Yang BC, Hsieh WC, Huang BM, Liu MY. Enhancement of TNF- $\alpha$ expression does not trigger apoptosis upon exposure of glial cells to lead and lipopolysaccharide. Toxicol. 2002; 178:183-191. https://doi.org/10.1016/S0300-483X(02)00225-1.

18. Mosmann T. Rapid colorimetric assay for cellular growth and survival: application to proliferation and cytotoxic assays. J Immunol Meth. 1983;65:55-63.

19. Kikuzaki H, Nakatani N. Antioxidant effect of some ginger constituents. J Food Sci. 1993;58:1407-1410. https://doi.org/10.1111/j.1365-2621.1993.tb06194.x.

20. Marklund S, Marklund G. Involvement of superoxide anion radical in the oxidation of pyrogallol and a convenient assay for superoxide dismutase. Eur J Biochem. 1974;47:468-474.

21. Blois MS. Antioxidant determination by the use of a stable free radical. Nature. 1958;181:1199-1200.

22. Folin O, Denis W. On phosphotungstic-phosphomolybdic compounds as color reagents. J Biol Chem. 1912;12:239-243.

23. A.O.A.C. Official methods of analysis (12 th). A.O.A.C., Washington D.C. 1995;127-130.

24. Tiffany CE, Garcia DE, Wu JN, Zmudzki J, Brattpn GR. Effects of lead on viability and intercellular metal content of $\mathrm{C} 6$ glioma cells. J Toxicol Environ Hlth. 1988;23:267-279. https://doi.org/10.1080/15287398809531112.

25. Borenfreud F, Puerner JA. A simple quantitative procedure using monolayer culture for cytotoxicity assay (HTD/NR-90). J Tiss Cult Meth. 1985;9:7-9.

26. Busselberg D, Evans ML, Haas HL, Carpenter DO. Blockage of mammalian and invertebrate calcium channels by lead. Neurotoxicol. 1993;14:249-258.

27. Jung IJ, Jang HS, Seo YM. Protective effect of Ajuga multiflora BUNGE extract on lead toxicity of environmental pollutant. J People Plants Environ. 2017;20:341-350.

28. Son YW, Jung IJ. Alleviating effect of Elscholtziae splendense extract on the induced toxicity by lead acetate of hair dye compound in cultured glioma cells. J Invest Cosm. 2012;8:115-120.

29. Kang SR, Park EY, Park MS, Park JH, Kim YC. Antioxidative and collagen synthetic abilities of Gardeniae fructus and Saururus chinensis water extract. J Invest Cosm. 2011;7:165-171.

30. Han SK, Kim SM, Pyo BS. Antioxidative effect of glasswort (Salicornia herbacea L.) on the lipid oxidation of pork. Kor J Food Sci Res. 2003;23:46-49.

31. Lim JA, Oh HJ, Baek SH. Antiaging ability of methanol extract from Euonymus alatus. J Cosm Pub Health. 2007;3:41-45.

32. Bressler J, Forman S, Goldstein GW. Phospholipid metabolism in neural microvascular endothelial cells after exposure to lead in vitro. Toxicol Appl Pharmacol. 1994;126:352-360.

33. El-Tantawy WH. Antioxidant effects of Spirulina supplement against lead acetate-induced hepatic injury in rats. J Tradit Complement Med. 2015;6:327-331. https://doi.org/10.1016/j. jtcme.2015.02.001. 